\title{
CUNeGEO
}

International Journal of Environment and Geoinformatics (IJEGEO) is an international, multidisciplinary, peer reviewed, open access journal.

\section{Determination of Risk Factors Caused by Ships in Port Planning}

\section{Mehmet Ersin Yücel, Cemil YURTÖREN}

\author{
Chief in Editor \\ Prof. Dr. Cem Gazioğlu \\ Co-Editor \\ Prof. Dr. Dursun Zafer Şeker, Prof. Dr. Şinasi Kaya, \\ Prof. Dr. Ayşegül Tanık and Assist. Prof. Dr. Volkan Demir \\ Editorial Committee (December 2019)
}

Assos. Prof. Dr. Abdullah Aksu (TR), Prof. Dr. Bedri Alpar (TR), Prof. Dr. Lale Balas (TR), Prof. Dr. Levent Bat (TR), Prof. Dr. Paul Bates (UK), Prof. Dr. Bülent Bayram (TR), Prof. Dr. Luis M. Botana (ES), Prof. Dr. Nuray Çağlar (TR), Prof. Dr. Sukanta Dash (IN), Dr. Soofia T. Elias (UK), Prof. Dr. A. Evren Erginal (TR), Assoc. Prof. Dr. Cüneyt Erenoğlu (TR), Dr. Dieter Fritsch (DE), Assos. Prof. Dr. Çiğdem Göksel (TR), Prof.Dr. Lena Halounova (CZ), Prof. Dr. Manik Kalubarme (IN), Dr. Hakan Kaya (TR), Assist. Prof. Dr. Serkan Kükrer (TR), Assoc. Prof. Dr. Maged Marghany (MY), Prof. Dr. Michael Meadows (ZA), Prof. Dr. Nebiye Musaoğlu (TR), Prof. Dr. Erhan Mutlu (TR), Prof. Dr. Masafumi Nakagawa (JP), Prof. Dr. Hasan Özdemir (TR), Prof. Dr. Chryssy Potsiou (GR), Prof. Dr. Erol Sarı (TR), Prof. Dr. Maria Paradiso (IT), Prof. Dr. Petros Patias (GR), Prof. Dr. Elif Sertel (TR), Prof. Dr. Nüket Sivri (TR), Assoc. Prof. Dr. Füsun Balık Şanlı (TR), Prof. Dr. Uğur Şanlı (TR), Duygu Ülker (TR), Assoc. Prof. Dr. Oral Yağcı (TR), Prof. Dr. Seyfettin Taş (TR), Assoc. Prof. Dr. Ömer Suat Taşkın (US), Dr. İnese Varna (LV), Dr. Petra Visser (NL), Prof. Dr. Selma Ünlü (TR), Assoc. Prof. Dr. İ. Noyan Y1lmaz (AU), Prof. Dr. Murat Yakar (TR), Assit. Prof. Dr. Sibel Zeki (TR) 


\title{
Determination of Risk Factors Caused by Ships in Port Planning
}

\author{
Mehmet Ersin Yücel ${ }^{1, *}$ iD , Cemil Yurtören ${ }^{2}$
}

\author{
${ }^{1}$ Ministry of Transport, C Blok Emek, Cankaya, Ankara -TR \\ ${ }^{2}$ Maritime Faculty, Department of Maritime Transportation and Management Engineering, Tuzla, TR \\ * Corresponding author:
}

E-mail: ersinkaptan@hotmail.com

How to cite: Yücel and Yurtören (2019). Determination of Risk Factors Caused by Ships in Port Planning, International Journal of Environment and Geoinformatics (IJEGEO), 6(3). 254-263. DOI: 10.30897/ijegeo.641434

\begin{abstract}
World Economy has been globalizing faster than ever as a result of the technological evolution. Increase of global trade brings the need of higher transportation capacity as bigger ships and port facilities. Port construction and expansion investments can be said to be supply to meet demand. Maritime safety is one of the factors affecting the zoning plan approval process in the port construction and extension investments. These factors mostly caused by the ship maneuver. One of the most widely used models is the Environmental Stress (ES) Model in risk assessment of navigation and ship manoeuvre.
\end{abstract}

ES Model measures the risk occurring around the ship during the berthing / unberthing manoeuvres performed in the simulation environment with the ports and ships that are modeled similar to the port project. But, it is not certain which parameter of the port project will be revised such as ship tonnage and length of the ship, port form and size etc. The main benefit of this study is taking precaution with measuring risk by specifying the risk factors and their weights using both ES Model and fuzzy logic method. Thus, the development plan and project evaluation process, which is under the duty and responsibility of the Turkish Ministry of Transport, will be carried out in terms of safety with the method proposed in this study. Another important contribution of this study is its originality in terms of clarification of raw outputs of ES model reports by using fuzzy logic method in scientific literature.

So, the revised port project will be realized by providing maritime safety. While port projects are approved by the Ministry of Transport within the scope of the legislation that determines the port planning process in question, the evaluation of Modeling Reports with fuzzy logic method will contribute to both fast and safe project design process.

Keywords: Environmental Stress (ES) Model, Fuzzy Logic, Risk Assessment, Port Planning

\section{Introduction}

Due to the geography it is located in, Turkey, which can be an intercontinental trade bridge in Europe - Central Asia - Middle East triangle, is a country that can be bypassed in terms of port cargo in transit loads and can only provide secondary port services. The main reason for this is that the planning for port infrastructure and port services has not been made until recently. In order to overcome this deficiency, a Master Plan Study was carried out in 2005 within the scope of the "Transportation Master Plan Strategy Project" and “Coastal Structures Master Plan” was made in 2010 by the Ministry of Transport. With these studies, the current situation of our country in the field of transportation, the internal and external conditions affecting our country and the things to be done have been revealed (Ministry of Transport, 2010). In addition, the necessary studies and arrangements have been made by the related institutions / organizations in order to conclude the port investment process in a certain order and in a short time in our country, whose porting policy is built upon a development strategy based on the investments of the private sector in this field. Most recently, the notification on Planning and Implementation Process in Coastal Structures and Facilities was published in 2011 and the port investment process has been determined (Ministry of Environment and Urbanization, 2011;). It is a need to be met in the development process that the capacity increase of port services, which should develop in parallel with a country's growing economy and foreign trade, is efficient and sustainable. For this purpose, assessing the risks arising from ship berthing / unberthing maneuvers affecting port capacity determination and design within the framework of regional and country-wide plans, directing port projects and conducting port services safely will bring thrifty and efficient coastal use which can be considered as scarce resource (Mersin et al., 2019). The institutions stated in the related notification of the Ministry of Environment and Urbanization in 2011 are required to give their opinions on the coastal structure projects (Ministry of Environment and Urbanization, 2011; Yüce and Gazioğlu, 2006). During the evaluation of the project in terms of maritime safety, which is one of the factors affecting the zoning plan approval process in the construction and extension investments of the new port by the Ministry of Transport and Infrastructure, it may be necessary to revise the port projects due to the risks arising from the ship maneuver. Various assessment models are used for the assessment of these risks (F1şkın \& Nas, 2013; Aydın \& Solmaz, 2019). One of the most 
widely used models is the Environmental Stress (ES) Model Inoue et al (1998). It is necessary to revise the high-risk port projects or to take additional preventive measures by measuring the risk occurring around the ship during the berthing / unberthing maneuvers performed in the simulation environment with the ports and ships that are modeled similar to the port project. However, since the risk factors and weights measured during ship maneuvers are not clearly known as a result of the ES Model report, it is not known how and to what extent the project will be revised. The main purpose of this study is to determine measures to be taken for damping of risk by specifying the risk factors and their weights using the ES Model and fuzzy logic method. A survey was conducted to determine the risk factors in high-risk port projects and expert opinions were taken and risks and their weights have been determined by using fuzzy logic method. Thus, the development plan and project evaluation process, which is under the duty and responsibility of the Ministry of Transport, will be fulfilled in a healthy manner with the method proposed in this study. Another important contribution of this study is its originality in terms of clarification of outputs of ES model reports by using fuzzy logic method in scientific literature.

\section{Literature review}

Various methods are used to investigate the risks that occur during the navigation of ships at sea. Şahin et al. (2018) used the "Ports and Waterways Safety Assessment (PAWSA)" method in their study for the risk assessment of maritime traffic in the the Strait of Istanbul (Bosphorus, SoI). Wang (2001) examined the "Formal Safety Assessment (FSA)" methodology, studied risk criteria for ship safety assessment, and discussed the possibilities for use in the maritime industry and ship operations. Using the IALA Waterway Risk Assessment (IWRAP) model, Jeong et al. (2012) analyzed the likelihood of marine accidents on the waterways in South Korea and aimed to improve the service provided by the Vessel Traffic Services (VTS). Young-Soo. et al. (2002) performed instantaneous and numerical risk measurements by using ES Model in ship maneuver scenarios in simulation environment. Sii et al. (2001) stated that it may not be appropriate to apply traditional safety analysis methods (eg. estimation risk analysis) to maritime structures and systems with a high degree of uncertainty in the concept, design and feasibility stage. Since it is possible to model human experience and knowledge with quantitative analysis without using numerical analysis by using Fuzzy Logic Method, it is argued that risk analysis with Fuzzy Logic Method is appropriate at the beginning of projects. Gucma and Pietryzkowski (2006) performed a ship's maneuver safety assessment using the Fuzzy Logic Method. The situations in which the ship makes dangerous navigation are determined by using simulation rest upon a method based on evaluating the situations that threaten navigation safety or which are thought to be threatened by the ship steering and management by using fuzzy logic elements. Wang et al. (2013) conducted an example of a hybrid method using two methods to investigate marine accidents and to take preventive measures. Besides Human Factor Analysis and Classification System, Bayesian Association Network is used to find the factors that cause accidents and preventive measures. In their study based on fuzzy logic method, Shenping Hu et al. (2007) proposed a new risk assessment approach by using FSA model to improve pilotage services in Shanghai port. Kim et al. (2013) confirmed the accuracy of the estimation by using fuzzy logic method as a result of examining the simulation performed by modeling the real shape and speed of the objects for realistic estimation of the collision risk. Son et al. (2009) evaluated the risk of collision and grounding by two methods. The first method is based on a fuzzy logic algorithm that evaluates the collision risk of ships. The second method is based on the ES Model in which the overall collision risks assessed by environmental stress values. Yurtören et al. (2008) investigated vessel traffic risks that are exposed by a new port installation by using ES Model. They presented the environmental objects-effects, vessel traffic and weather conditions in the model.

Both qualitative and quantitative research methods are used in this methodology developed for risk assessment of ship maneuvers. In the qualitative research method, the knowledge and experience of the pilot captains who give expert advice to the ship masters during the maneuvers of the ship are used, and in the quantitative research method, numerical and statistical information are used (Nas, et al., 2006).

\section{Ship Maneuver Risk Assessment}

Various models are used to evaluate the risks that may affect the safety of ships in ports and waterways, such as; PAWSA, IWRAP, FSA, ES Models. The FSA is a structural and systematic methodology aimed at improving maritime safety including the safety of life, protection of health, marine environment and property, using risk and cost benefit analysis. It consists of five steps: Identification of hazards (list of all accident scenarios related to potential causes and consequences), Assessment of risks (assessment of risk factors), Risk control options (develop regulatory measures to control and mitigate identified risks), Cost benefit analysis (determination of cost effectiveness of each risk control option) and Recommendations for decision-making (information on hazards, associated risks and costeffectiveness of alternative risk control options) (Nas, 2006; URL 1). PAWSA proposes the development of policies and procedures that promote dialogue at the port site to improve the efficiency and safety of maritime traffic use. It is aimed to ensure safe maritime traffic by conducting a workshop to meet the stakeholders using the waterway to reach the set targets. It identifies risks that threaten waterway safety, assesses possible mitigation measures, and provides the basis for implementing them (URL 2). Within PAWSA process; during the project development phase, existing information in the relevant region is collected to improve navigation safety and support the maritime transport system. The coordination and cooperation between the 
government and the private sector is improved and stakeholders are involved in decisions affecting them. The role of stakeholders in the working group is enhanced and strengthened. Its role in the management of ship traffic in the maritime area where the administration is responsible is supported and strengthened (URL 3). IWRAP is used to detect the possibility of an accident in a waterway. It is assumed that there is the possibility of an accident if the ships, passing near land or another ship, do not maneuver for avoiding collision. It is a method based on an evaluation by using the depth, weather, previous accident statistics and observed real ship traffic movements together (FriisHansen, 2008). ES model is designed to quantify the degree of stress generated by the topographic and traffic environment on the ship. The environmental conditions that affect the risk analysis and evaluation results of the ES model are as follows: Topographic conditions (land, shallows, breakwater, buoy, fishing nets, anchored or moored ships and other fixed or floating obstacles),
Traffic conditions (traffic flow, ship traffic intensity), External factors (wind, current, etc.). There is no stress on the ship since there is no limited water area in the open sea and there is sufficient time to collision (TTC). On the contrary, on ships navigating in narrow channels, there is stress within the framework of environmental conditions such as topographic conditions, ship traffic and ship route. This stress may be affected due to the characteristics of the ship (length, type, tonnage, maneuvering circle, etc.). Stress level is defined as values between $0-1000$ at different risk levels. These definitions are as shown in table 1; negligible risk between 0-500, Marginal risk between with 500-750, Critical risk values between with 750-900. At the same time the value of 750 has been accepted as an unacceptable risk limit and is an important feature of this model. The values between with 900-1000 are catastrophic and this means that will result in a near-miss or an accident occurred (Terzi \& Gazioğlu 2014; 2016; Nas, 2015).

Table 1. Stress values and acceptance criteria

\begin{tabular}{|c|c|c|c|c|}
\hline Stress Factor & Marine Perception & Stress Value & Stress Level & Acceptance Criteria \\
\hline 0 & Very Safe & \multirow{3}{*}[0]{} & \multirow{3}{*}{ NEGLIGIBLE } & \multirow{4}{*}{ ACCEPTABLE } \\
\hline 1 & Safe & & & \\
\hline 2 & Little Safe & & & \\
\hline 3 & Medium Safety & [500] & MARGINAL & \\
\hline 4 & Little Dangerous & {$[750]$} & CRITICAL & \multirow{3}{*}{ UNACCEPTABLE } \\
\hline 5 & Moderate Dangerous & {$[900]$} & \multirow{2}{*}{ CATASTROPHIC } & \\
\hline 6 & Very Dangerous & {$[1000]$} & & \\
\hline
\end{tabular}

\section{Materials and Methods Fuzzy logic method}

Zadeh (1965) first used the concept of fuzzy logic and gained literature. The classification of factors and criteria without strict limitations is possible with fuzzy logic. Clearing is a convenient method for identifying or solving uncertainties and uncertain problems in life. Fuzzy logic is a multivariate theory of the mean plane such as "medium", "high", "low instead of certain judgments such as “yes" or "no", “right” or "false (Başbuğ, 1994).

Fuzzy clusters are defined by membership functions and the membership function of fuzzy set A is represented by $\mu \mathrm{A}(\mathrm{x})$. Membership of a factor in a cluster takes a value between 0 and 1. Fuzzy numbers are used in fuzzy sets for ease of operation. Triangular fuzzy numbers, a special class of fuzzy numbers, are used in the majority of studies for this purpose. The triangular fuzzy number (A) is expressed by three real numbers $(1 \leq \mathrm{m} \leq \mathrm{u})$. (Kaya, 2010).

In the membership function of the triangular fuzzy number defined based on these numbers, m represents the most possible value of the fuzzy number, and $\mathrm{l}$ and $\mathrm{u}$ values indicate the lower and upper limits of the fuzzy scope, respectively. The steps followed in fuzzy logic applications are explained in the following sections respectively (Kaya, 2010).

\section{Weighting stage}

At this stage, experts produce their own subjective views for each factor. Due to limited resources or physical constraints, in some cases, expert inferences are used to eliminate uncertainty (Rausand and Hoyland, 2004, p.6). Expert inference is a preferred method of scientific consensus for rare events. Expert extraction allows us to use parameters related to experts called "educated estimation”. In addition, this methodology allows experts to make predictions only in their area of expertise, revealing uncertainties as quantitative probabilities.

This technique is used in many disciplines. Psychology, mathematics, Bayesian statistics and decision analysis are some of the areas of application of the expert inference method for obtaining stochastic data. Subjective probabilities may need to be digitized in cases where evidence is lacking because it cannot be reasonably obtained, data can only be obtained from similar events, and model or data sources overlap (Korta et al., 1996, p.5). According to Ford and Sterman (1998), experts' decisions are influenced by their perspectives and goals. In this respect, it is almost impossible to make 
objective decisions and attention should be paid to the selection of experts. Another important issue is whether a homogeneous expert group or a heterogeneous expert group is selected. The homogeneous group consists of experts who are interested in the same job, for example, only employees. The heterogeneous group of experts is concerned with experts in various fields, both being scientists and workers. The diversity of judgments in homogeneous groups is expected to be smaller than the heterogeneous group. It is more advantageous than homogeneous group judgments by providing different judgments and opinions with different experiments with heterogeneous group. Their essence is based on their experience in a field in the center, the core criteria of appointing experts based on a specialist and primary education specialist of knowledge. The decision will affect the decisions, evaluations and analytical behaviors of the experts (Şenol, 2014).

In this study, heterogeneous expert opinion was used to calculate the probability of uncertain events and to calculate the weight scores of experts symbolized with "w". Linguistic terms are used in expert evaluations. The purpose of this step is to get the opinions of experts for each factor. According to Zadeh (1965), traditional quantitative expression in traditional terms is versatile in dealing with situations that are too poorly defined or too complex to be expressed.

\section{Combining stage}

Experts can make different decisions because they have different ideas depending on their experience and knowledge. The issue is to bring all judgments together and to reach a compromise. Hsu and Chen (1994) proposed an algorithm for combining the judgments of both homogeneous and heterogeneous groups. Assume that each expert expresses his or her view in linguistic terms that are predetermined in specific contexts. Linguistic terms are converted to fuzzy numbers using the appropriate algorithm described below.

\section{Agreement degree (Similarity Degree)}

The symbol " $S$ ” shall symbolize the degree of similarity of the expert opinions indicated by the symbol "R". While $S_{u v}\left(\tilde{\mathrm{R}}_{u}, \tilde{\mathrm{R}}_{v}\right) \in[0,1]$, the similarities of $E_{v}$

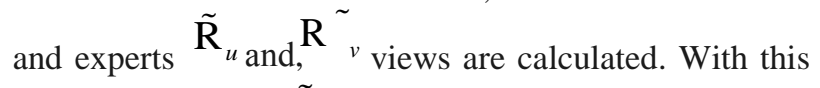
approach, $\quad \tilde{\mathrm{R}}_{u}=\left(\mathrm{r}_{u 1}, \mathrm{r}_{u 2}, \mathrm{r}_{u 3}, \mathrm{r}_{u 4}\right)$ and $\tilde{\mathrm{R}}_{v}=\left(\mathrm{r}_{v 1}, \mathrm{r}_{v 2}, \mathrm{r}_{v 3}, \mathrm{r}_{v 4}\right)$ are two standard trapezoidal fuzzy numbers.

The similarity ratio between these two expert opinions is calculated by the similarity function given below;

$$
S\left(\tilde{\mathrm{R}}_{u}, \tilde{\mathrm{R}}_{v}\right)=1-\frac{1}{4} \sum_{i=1}^{4}\left|r_{u i}-r_{v i}\right|
$$

While $S\left(\tilde{\mathrm{R}}_{u}, \tilde{\mathrm{R}}_{v}\right) \in[0,1]$, Increasing the value of $S\left(\tilde{\mathrm{R}}_{u}, \tilde{\mathrm{R}}_{v}\right)$ indicates that the similarity between these two fuzzy numbers increases.

$S\left(\tilde{\mathrm{R}}_{u}, \tilde{\mathrm{R}}_{v}\right)$ is equal to 1 , which means that expert opinions are the same.

Average degree of agreement of experts $A A\left(E_{u}\right)$

$$
\begin{aligned}
& E_{u}(u=1,2, \ldots, \mathrm{N}) \\
& A A\left(E_{u}\right)=\frac{1}{N-1} \sum_{\substack{u \neq v \\
v=1}}^{N} S\left(\tilde{\mathrm{R}}_{u}, \tilde{\mathrm{R}}_{v}\right)
\end{aligned}
$$

" $\mathrm{N}$ sembol symbolizes the total number of experts.

Calculation of relative expert agreement degrees $R A\left(E_{u}\right)$

$$
\begin{array}{r}
\text { While } E_{u}(u=1,2, \ldots, \mathrm{N}), \\
\qquad R A\left(E_{u}\right)=\frac{A A\left(E_{u}\right)}{\sum_{u=1}^{N} A A\left(E_{u}\right)}
\end{array}
$$

Estimation of expert consensus coefficient (CC) degree $C C\left(E_{u}\right)$

$$
C C\left(E_{u}\right)=\beta \cdot w\left(E_{u}\right)+(1-\beta) \cdot R A\left(E_{u}\right)(\text { Eq. 5) }
$$

While $(0 \leq \beta \leq 1)$, “ $\beta$ ”, relaxation factor shows the importance of $w\left(E_{u}\right)$ on $R A\left(E_{u}\right), \beta=0$, indicates that the evaluation of experts by the researcher. $\beta=1$, indicates that the expert consensus rating coefficient is considered to be the same as the expertise significance weighting.

The consensus degree coefficient of each expert is a good measure for evaluating the relativity of the expert opinion (Lavasani et al., 2011). It is the decision maker's responsibility to evaluate the value of $\beta$.

- Consolidation of expert opinion, $\tilde{R}_{A G}$

$\tilde{R}_{A G}=C C\left(\mathrm{E}_{1}\right) \times \tilde{R}_{1}+C C\left(\mathrm{E}_{2}\right) \times \tilde{R}_{2}+\ldots+C C\left(\mathrm{E}_{M}\right) \times \tilde{R}_{M}$ (Eq. 6)

\section{Defuzzification Stage}

The purpose of the defuzzification process is to obtain measurable results in fuzzy logic. According to Zhao and Govind (1991), defuzzification problems arise from the application of fuzzy control applications to the industrial process. Clarifying fuzzy numbers is crucial to making decisions on fuzzy issues. In this study, the most commonly used field center method was developed by Sugeno in 1985 (Sugeno, 1999). 


$$
\begin{aligned}
& X^{*}=\frac{\int \mu_{i}(x) x d x}{\mu_{i}(x)} \\
& X^{*}=\frac{\int_{r_{1}}^{r_{2}} \frac{x-r}{r_{2}-r_{1}} x d x+\int_{r_{2}}^{r_{3}} \frac{r_{3}-x}{r_{3}-r_{2}} x d x}{\int_{r_{1}}^{r_{3}} \frac{x-r_{1}}{r_{2}-r_{1}} d x+\int_{r_{2}}^{r_{3}-x} \frac{r_{3}}{r_{3}-r_{2}} d x}=\frac{1}{3}\left(\mathrm{r}_{1}+r_{2}+r_{3}\right)
\end{aligned}
$$

In case is a clarified output, is a collective membership function and $\mathrm{x}$ is the output variable. The formula given above can show triangular and trapezoidal fuzzy numbers. The clarification of fuzzy numbers can be explained as follows:

Clarification of trapezoidal fuzzy numbers is explained below:

$$
X^{*}=\frac{\int_{r_{1}}^{r_{2}} \frac{x-r}{r_{2}-r_{1}} x d x+\int_{r_{2}}^{r_{3}} x d x+\int_{r_{3}}^{r_{4}} \frac{r_{4}-x}{r_{4}-r_{3}} x d x}{\int_{r_{1}}^{r_{2}} \frac{x-r_{1}}{r_{2}-r_{1}} d x+\int_{r_{2}}^{r_{3}} x d x+\int_{r_{3}}^{r_{4}} \frac{r_{4}-x}{r_{4}-r_{3}} d x}=\frac{1\left(\mathrm{r}_{4}+r_{3}\right)^{2}-r_{4} r_{3}-\left(\mathrm{r}_{1}+r_{2}\right)^{2}+r_{1} r_{2}}{3}
$$

\section{Integration of Fuzzy Logic to ES Model}

The factors that constitute the risk values found in the ES Model Report results are weighted using fuzzy logic method. Risk factors are weighted by applying fuzzy logic method separately to 30 docking scenarios performed in simulation environment. By analyzing the results, the risks that occur during ship maneuvering in port projects are evaluated according to their weights and the possibility of damping. Thus, corrective measures can be provided to ensure safe maneuvering. During this process, initially 10 experts in the subject are asked what the risk factors are for each ES scenario. Experts' opinions are weighted according to their educational level and experience. Then, the comments made by asking to evaluate the effects of the risk factors on the results of the model separately as linguistic (very high, low, very low, etc.) are evaluated with fuzzy logic. Different commercial ports are selected across Turkey. The risk assessments reached by using ES Model on 30 different maneuvering simulations performed at these ports are examined. In order to determine the weights of the risk factors which are the source of the obtained risk assessment values by using fuzzy logic method, a survey of 16 questions is prepared for each maneuver scenario previously performed and conducted for 30 scenarios with 10 experts. Within the scope of the survey, experts are asked to weight the factors that constitute the risk values assessed because of berthing maneuvers by giving

\begin{tabular}{|c|c|c|}
\hline Parameter & Classification & Weighting Factor \\
\hline \multirow{5}{*}{ Position } & Academician & 5 \\
\hline & Manager & 4 \\
\hline & Expert & 3 \\
\hline & Captain & 2 \\
\hline & Chief Officer & 1 \\
\hline \multirow{5}{*}{ Service Duration Onboard (year) } & $16 \geq$ & 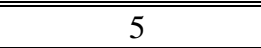 \\
\hline & $11-15$ & 4 \\
\hline & $6-10$ & 3 \\
\hline & $3-5$ & 2 \\
\hline & $\leq 2$ & 1 \\
\hline \multirow{5}{*}{ Service Duration Onshore (year) } & $16 \geq$ & 5 \\
\hline & $11-15$ & 4 \\
\hline & $6-10$ & 3 \\
\hline & $3-5$ & 2 \\
\hline & $\leq 2$ & 1 \\
\hline \multirow{5}{*}{ Education Level } & PhD & 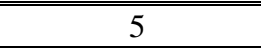 \\
\hline & Master & 4 \\
\hline & Bachelor & 3 \\
\hline & Associate & 2 \\
\hline & High school & 1 \\
\hline
\end{tabular}
values between with 1-7.

Table 2. Expert Weight Determination Criteria 
Table 3. Expert weighting score calculation

\begin{tabular}{|c|c|c|c|c|c|c|c|c|c|c|}
\hline $\begin{array}{c}\text { Expert } \\
\text { Number }\end{array}$ & Position & $\begin{array}{c}\text { Service Time } \\
\text { Onboard } \\
\end{array}$ & \begin{tabular}{|c|c|} 
Service Time \\
Onshore
\end{tabular} & $\begin{array}{c}\text { Education } \\
\text { Level }\end{array}$ & \multicolumn{4}{|c|}{$\begin{array}{l}\text { Weighting } \\
\text { Factor }\end{array}$} & $\begin{array}{c}\text { Total } \\
\text { Weight } \\
\end{array}$ & $\begin{array}{c}\text { Weighting } \\
\text { Score }\end{array}$ \\
\hline 1 & Master & $3-5$ & $>=26$ & Bachelor & 2 & 2 & 5 & 3 & 12 & 0.11 \\
\hline 2 & $\begin{array}{l}\text { Chief } \\
\text { Officer }\end{array}$ & $3-5$ & $6-10$ & Master & 1 & 2 & 2 & 4 & 9 & 0.08 \\
\hline 3 & $\begin{array}{c}\text { Chief } \\
\text { Officer }\end{array}$ & $<3$ & $6-10$ & Master & 1 & 1 & 2 & 4 & 8 & 0.07 \\
\hline 4 & Master & $6-10$ & $6-10$ & Bachelor & 2 & 3 & 2 & 3 & 10 & 0.09 \\
\hline 5 & Master & $6-10$ & $6-10$ & Bachelor & 2 & 3 & 2 & 3 & 10 & 0.09 \\
\hline 6 & Master & $6-10$ & $>=16$ & Bachelor & 2 & 3 & 0 & 3 & 8 & 0.07 \\
\hline 7 & $\begin{array}{l}\text { Chief } \\
\text { Officer }\end{array}$ & $3-5$ & $11-15$ & Bachelor & 1 & 2 & 3 & 3 & 9 & 0.08 \\
\hline 8 & Manager & $6-10$ & $11-15$ & $P h D$ & 4 & 3 & 3 & 5 & 15 & 0.14 \\
\hline 9 & Manager & $6-10$ & $11-15$ & Master & 4 & 3 & 3 & 4 & 14 & 0.13 \\
\hline 10 & $\begin{array}{l}\text { Academ } \\
\text { ician }\end{array}$ & $3-5$ & $6-10$ & $P h D$ & 5 & 2 & 2 & 5 & 14 & 0.13 \\
\hline
\end{tabular}

As a result, 4800 answers are reached. Before the evaluation of the survey results with fuzzy logic method, the answers and numerical equivalents are determined as follows; Very low $=1$, Low $=2$, Moderate Low $=3$, Moderate $=4$, Moderate High $=5$, High $=6$, Very High $=7$. As it is shown in table 2, the experts who answered the survey are weighted according to their experience, education and professional positions.

The experts whose opinions were taken in the survey study were classified according to the criteria specified in table 3. Thus, they are weighted according to their level of expertise.

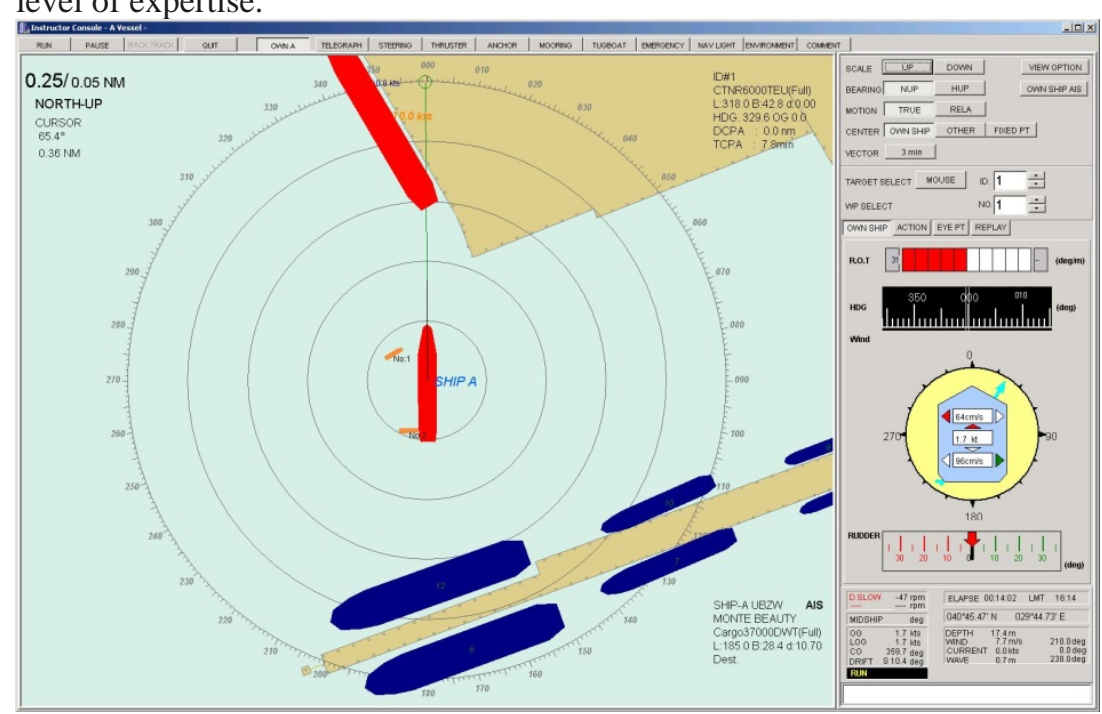

Figure 1. Approaching to the berth

\section{Results}

The berthing scenario carried out by using Real Time Simulation. The maneuver screenshots obtained as a result of ship maneuver simulation are presented in figure 1 to figure 4 . The berthing at the pier was approached from the starboard side.

An advantageous condition was obtained for maneuvering. There was a wide area to alter course the the port. 


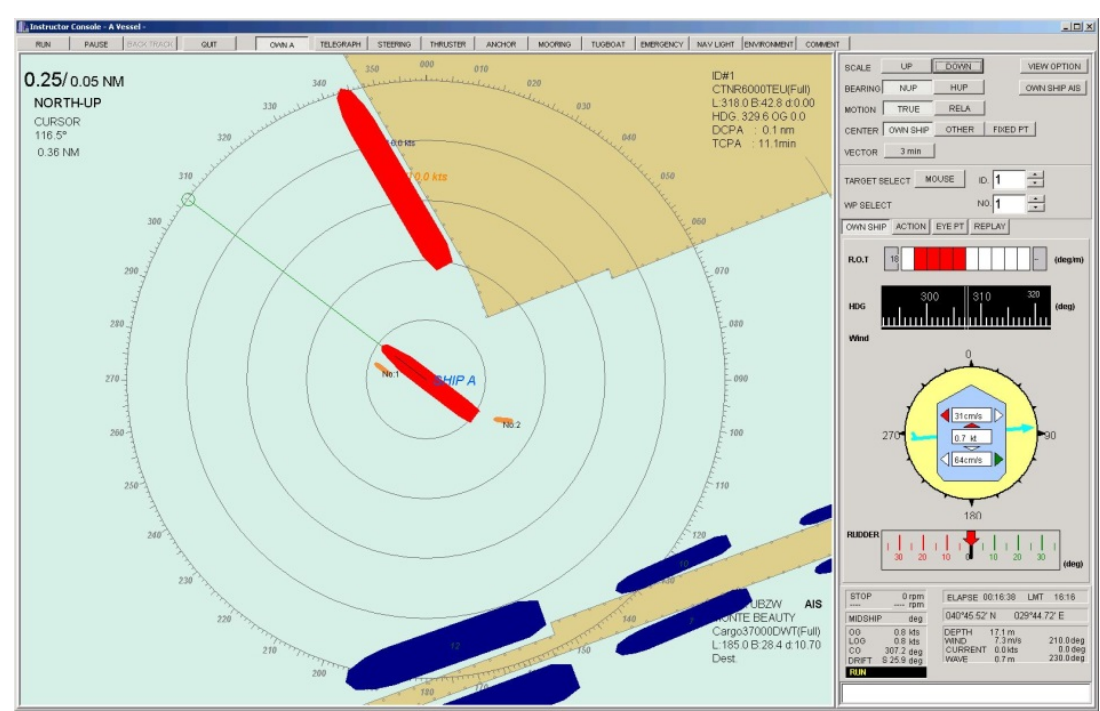

Figure 2. Maneuvering to the port side.

During the maneuver, an easy and quick rotation was achieved as there the ship was underway at the turning

area. With assistance of two tugboats, the ship was

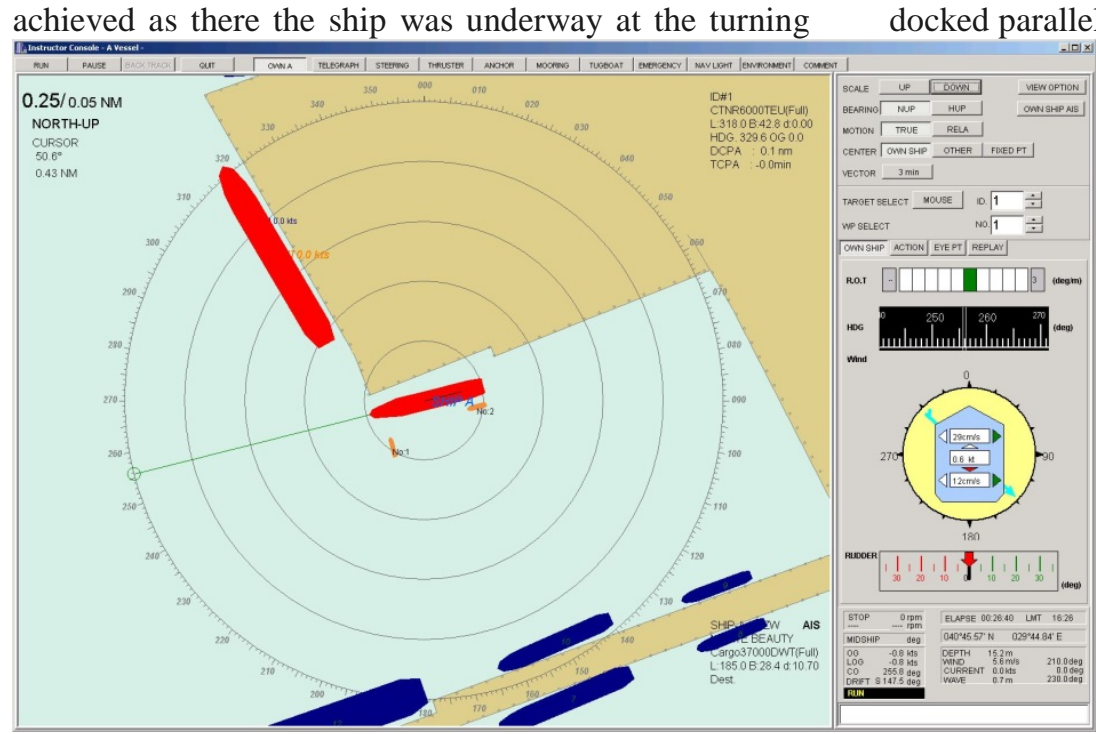

Figure 3. Docking parallel to the pier

While heading to seaward, it is easier to move forward increasing the safety of the maneuver, making it easier to and slower backwards during ship's engine usage, thus control the ship.

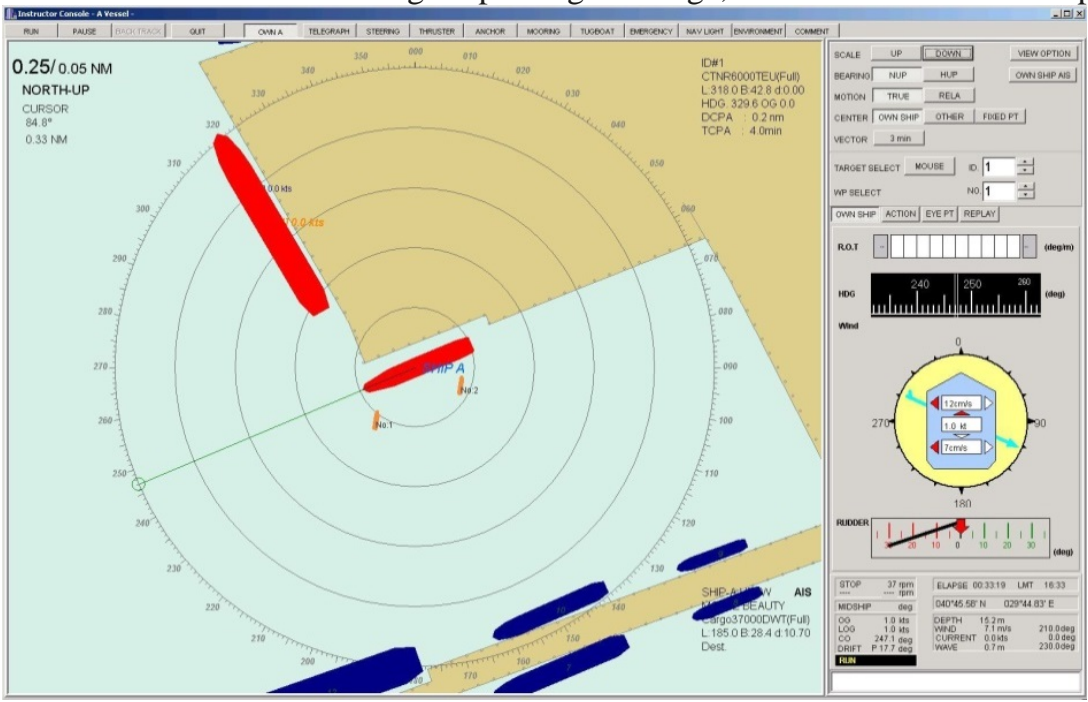

Figure 4. Berthing completed 
ES Model calculates the maneuver difficulties dynamically during the ship maneuver and indicates the colour of the maneuver difficulty level shown in Figure 5.

The Risk types and values measured by ES Model are presented below:

- Maneuver difficulty: : \% 63,4

- Marginal Risk: \& 30,3
- $\quad$ Critial Risk: \& 6,3

The survey results for the scenario are presented in table 4.

As a result of the fuzzy logic method, the weights of the docking simulation risk factors are presented in table 5. The three risk factors with the highest effect are determined as ship tonnage, wind and ship engine use.

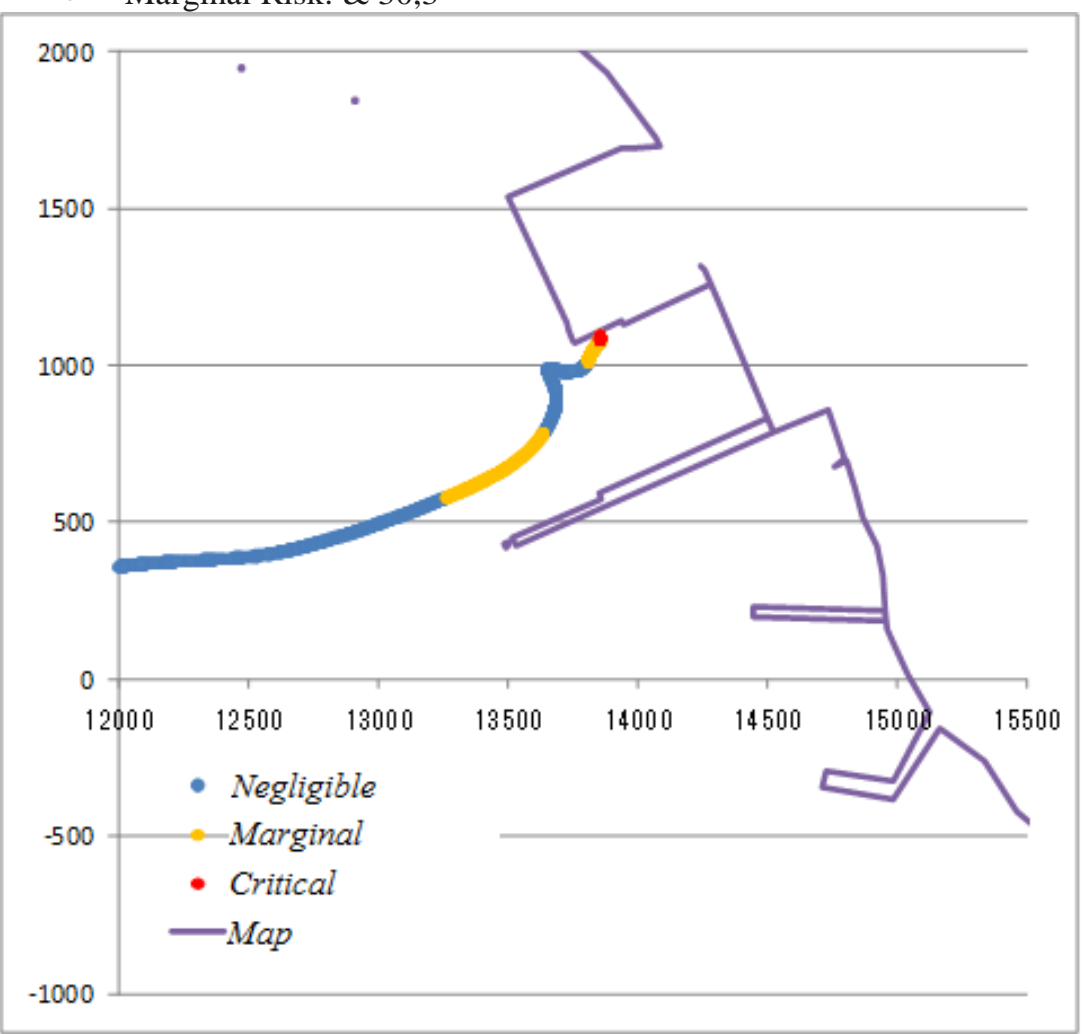

Figure 5. Maneuver difficulties which are loaded by the berthing vessel

Table 4. Survey results for the scenario

\begin{tabular}{|l|l|l|l|c|c|c|c|c|c|c|}
\hline \multirow{2}{*}{ Criteria } & \multicolumn{9}{c|}{ Expert no } \\
\cline { 2 - 11 } & E1 & E2 & E3 & E4 & E5 & E6 & E7 & E8 & E9 & E10 \\
\hline Ship Length & & & & & & 2 & & & & \\
\hline Ships in vicinity & & & & 3 & 2 & 3 & 3 & 3 & & \\
\hline Tug Usage & & & & & 2 & 3 & 3 & 3 & 5 & 3 \\
\hline Wind & & & & & & & & & & \\
\hline Wave & & & & & & & & 2 & & \\
\hline Stream & 3 & & & & & & & 2 & & \\
\hline Depth & & & & & & & & & & \\
\hline Ship Tonnage & & 3 & & & 2 & 3 & 3 & 3 & 3 & 4 \\
\hline Maneuvering Area & 6 & & 6 & 5 & & 3 & 5 & 4 & 4 & 4 \\
\hline Usage og Ship's Engine & & & & & & & & & & \\
\hline Maneuvering Type & & 6 & & & & & & & & \\
\hline Mooring Type & & & & & & & & & & \\
\hline Buoy Mooring & & & & & & & & & & \\
\hline Anchoring & & & & & & & & & & \\
\hline Bow/Aft Truster & 4 & & & 2 & 3 & & 4 & & 3 & 3 \\
\hline Pear Design & & 3 & & & & & & & & \\
\hline
\end{tabular}


Table 5. The weights of the docking simulation risk factors

\begin{tabular}{||l|c||l|c||}
\multicolumn{1}{|c|}{ Risk Factors } & Weights & \multicolumn{1}{c||}{ Risk Factors } & Weights \\
\hline Ship Length & & Maneuvering Area & 35 \\
\hline Ships in vicinity & 11 & Usage og Ship's Engine & \\
\hline Tug Usage & 18 & Maneuvering Type & \\
\hline Wind & & Mooring Type & \\
\hline Wave & & Buoy Mooring & \\
\hline Stream & & Anchoring & 16 \\
\hline Depth & Bow/Aft Truster & \\
\hline Ship Tonnage & & & \\
\hline
\end{tabular}

\section{Conclusion}

Maritime safety is one of the factors affecting the zoning plan approval process in the port construction and extension investments. These factors mostly arise from the ship maneuver. One of the most widely used models is the ES Model in risk assessment of navigation. ES Model measures the risk occurring around the ship during the berthing / unberthing maneuvers performed in the simulation environment with the ports and ships that are modeled similar to the port project. But, it is not known how and to what extent the project will be revised. The main purpose of this study is to determine measures to be taken for damping of risk by specifying the risk factors and their weights using both ES Model and fuzzy logic method. Thus, the development plan and project evaluation process, which is under the duty and responsibility of the Turkish Ministry of Transport, will be fulfilled in a healthy manner with the method proposed in this study. Another important contribution of this study is its originality in terms of clarification of raw outputs of ES model reports by using fuzzy logic method in scientific literature. Port investments and planning are carried out by the private sector and there is no holistic planning in fact. Ports that are planned and put into operation with a private pier/dock approach cause scattered and distorted harbor formations. Since the transportation infrastructure is not planned in a coordinated way, the back area causes waste of resources and logistics investments that are far from efficient. In the areas where there are more than one consecutive port facilities, it is possible occurring high risk caused by ship maneuvering due to very close quay/pier planning. The periodical revision of coastal planning will ensure to transport with high efficiency in the port areas and industrial area. In addition, it will be possible to eliminate or reduce the risk in terms of ship maneuver by determining risk factors and their weight. So, the revised port project will be realized by providing maritime safety. While the Ministry of Transport within the scope of the legislation that determines the port planning process in question approves port projects, the evaluation of Modeling Reports with fuzzy logic method will contribute to both fast and safe project design process.

The awareness that ports are an industrial area of activity has led many environmental organizations to become more active in order to monitor the environmental problems posed by port activities. Developing environmental approaches now require proactive measures before an accident develops. It is obvious that this study will contribute in this context.

\section{References}

Aydın, D., Solmaz, DS. (2019). Modelling of the Oil Spill in M/V LADY TUNA Accident and the Evaluation of the Response Operation in Simulated Condition with PISCES II, International Journal of Environment and Geoinformatics (IJEGEO), Vol. 6(2), 213-224.

Başbuğ, A. (1994). “Fuzzy Technology”, Byte, February, 147-152.

Fışkın, R., Nas, S. (2013). A Content Analysis of the International Journal on Marine Navigation and Safety of Sea Transportation from 2007 to 2012.Trans. Nav. Journal, 7(1), 145-149.

Ford, D. Sterman, J. D. (1998). Expert knowledge elicitation to improve mental and formal models. System Dynamics Review, 14(4), 309-340

Friis-Hansen, P. (2008) Basic Modelling Principles For Prediction of Collision and Grounding Frequencies Working Document

Gucma, L., Pietrzykowski, Z. (2006). Ship Manoeuvring in Restricted Areas: An Attempt to Quantify Dangerous Situations Using a Probabilistic-Fuzzy Method. Journal of Navigation, 59(2), 251-262.

Hsu, H. M. Chen, T. C. (1994). Aggregation of fuzzy opinion under group decision making. Fuzzy Sets and Systems, 79(3), 279, 285

Hu, S., Fang, Q., Xia, H., Xi, Y. (2007). Formal safety assessment based on relative risks model in ship navigation. Reliability Engineering \& System Safety. 92. 369-377.

Inoue, K., Masuda, K., Sera, W. (1998). Guidelines to Assess the Safety of Marine Traffic-I : Evaluation of Shiphandling Difficulty based on the Environmental Stress Model. The Journal of Japan Institute of Navigation. 98. 225-234. 10.9749/jin.98.225.

Kim, KI., Jeong JS., Park GK. (2012). A Study on the Quantitative Risk Assessment of Mokpo Entrance Waterway by IWRAP, Proceedings of 2012 KOSOMES Spring Conference, pp. 253-256.

Korta, JP., Lee, MP., Einsberg, N., Dewispelare, A. (1996). Branch technical position on the use of expert elicitation in the high-level radioactive waste program. 1st Ed. U.S. Nuclear Regulatory Comission. 
Mersin, K., Bayırhan, İ., Gazioğlu, C. (2019). Review of $\mathrm{CO} 2$ Emission and Reducing Methods in Maritime Transportation, Thermal Sci. 1-8.

Ministry of Environment and Urbanization (2011), Notification Regarding Planning and Implementation Process in Coastal Structures and Facilities, Ankara, Turkey

Ministry of Transport (2005), Transportation Master Plan Strategy Project, Ankara, Turkey

Ministry of Transport (2010), Coastal Structures Master Plan, Ankara, Turkey

Nas, S. (2006). Gemi operasyonlarının yönetiminde kaptanin bireysel karar verme süreci analizi ve bütünleşik bir model uygulaması (Yayımlanmamış Doktora Tezi), Dokuz Eylül Üniversitesi Sosyal Bilimler Enstitüsü, İzmir.

Nas, S. (2015). The definitions of safety and security, Journal of ETA Maritime Science, Vol. 3(2), 53-54.

Nas, S., Altuğ Ş. K., Y1lmazel M. (2006). A Study on the Enhancement of Safety Culture in Harbour Pilotage and Towage Organizations. 18. Congress of the International Maritime Pilots Association (IMPA) 20th-24th November 2006. Havana, Cuba.

Park, Y.S., Jae-Yong, J., Inoue K. (2002). A Study on Assessment of Vessel Traffic Safety Management by Marine Traffic Flow Simulation. Journal of the Korea Society for Simulation. 11.

Şenol Y.E.(2014), Fault Tree Analysis of Chemical Cargo Contamination By Fuzzy Approach (MSc thesis), Istanbul Technical University, Istanbul, Turkey

Sii, H., Wang, J., Ruxton, T. (2001). A Fuzzy-LogicBased Approach to Subjective Safety Modelling for Maritime Products. Safety and Reliability, 21(2), pp.65-78.

Son, N.S., Kim, S.Y., Gong, I.Y. (2009). Study on the Estimation of Collision Risk of Ship in Ship Handling Simulator using Fuzzy Algorithm and Environmental Stress Model. Journal of Korean navigation and port research.

Terzi, H., Gazioğlu, C. (2014). Finding Solutions before Accidents Happen, XVIII. IALA AISM 2014.

Terzi, H., Gazioğlu, C. (2014). Pozitif Emniyet Kültürü Temel Öğelerini Esas Alan Kazasay Olayları (Near Miss) Raporlama Sistemi. Dokuz Eylül Üniversitesi Denizcilik Fakültesi Dergisi, 6(1), 23-58.

Terzi, H., Gazioğlu, C. (2016). New Era In Maritime Safety: Safety Culture, 13th International IALA VTS Symposium, International framework for VTS and national regulatory provisions.

URL 1 (2019). Formal Safety Assessment. http://www.imo.org/en/OurWork/Safety/SafetyTopic s/Pages/FormalSafetyAssessment.aspx (Acces. Oct. 2019).

URL 2 (2019). Ports and Waterways Safety Assessment. https://www.navcen.uscg.gov/?pageName=pawsaMai n (Acces. Oct. 2019).

URL 3 (2019). Ports and Waterways Safety Assessment (PAWSA) https://www.dco.uscg.mil/PAWSA/ (Acces. Oct. 2019)
Wang, J.(2001).Current status of future aspects of formal safety assessment of ships. Safety Science, 38, 19-30.

Wang, Z., Zoghi, M., Hutter, F., Matheson, D., N. de Freitas. (2013) Bayesian Optimization in a Billion Dimensions via Random Embeddings. ArXiv e-prints, January

Yüce H., Gazioğlu C. (2006). "Maritime Security Challenges Ahead in the Black Sea", Journal of Black Sea/Mediterranean Environment, Vol.12 (3): 233-250.

Yurtören C., Duru O., Satir T. (2008). The Environmental Effects of Projected Container Terminal to the Safely Manoeuvring International Journal on Marine Navigation and Safety of Sea Transportation Vol. 2 No. 1

Zadeh, LA. (1965) "Fuzzy Sets." Information and Control, vol. 8, no. 3, 338-353,

Zhao, R. Govind, R. (1991). Defuzzification of fuzzy intervals. Fuzzy Sets and Systems, 43(1), 45-55. 